Research Article

\title{
The effect of calcium channel blockers against scopolamine induced cognitive impairment and oxidative stress
}

\author{
D. Seshadri Sekhar ${ }^{1}$, B. K. Shwetha ${ }^{2}$, B. Haimavathi ${ }^{1}$, P. Vikram ${ }^{1}$
}

${ }^{1}$ Department of Pharmacology,
S. M. T. Sarojiniramulamma
College of Pharmacy,
Mahabubnagar, Telangana,
India
${ }^{2}$ Department of Pharmacology,
Sr. K. V. College of Pharmacy,
Chickballapur, Karnataka, India

Received: 27 July 2016

Revised: 29 July 2016

Accepted: 31 August 2016

*Correspondence to:

Dr. Devangam Sheshadri

Shekar,

Email: sheshadrishekar@ gmail.com

Copyright: (C) the author(s), publisher and licensee Medip Academy. This is an openaccess article distributed under the terms of the Creative Commons Attribution NonCommercial License, which permits unrestricted noncommercial use, distribution, and reproduction in any medium, provided the original work is properly cited.

\begin{abstract}
Background: the present work has been planned to find out the effect of calcium channel blockers on learning and memory. there are numerous reports indicating that calcium channel blockers (CCBS) impair memory and learning and on the other side there are reports indicating that CCBS improve memory and learning. This contradictory reports led us to investigate the effect of CCBS on memory and learning by taking three different types of calcium channel blockers verapamil, nimodipine and diltiazem.

Methods: The methods used were elevated plus maze and novel recognition object tests. Ten groups of animals were treated with CCBS and scopolamine. Both prophylactic and curative studies were carried out.

Results: It was evident from our studies that the CCBS effectively antagonized the scopolamine induced cognitive impairment in the paradiagms studied. The inflex ratio and novel object discrimination index also increased indicating decrease in the trancefer latencies. CCBS showed good protection against scopolamine induced cognitive.

Conclusions: In our Studies we observed that verapamil was good in prophylactic studies and diltiazem in curative studies.
\end{abstract}

Keywords: CCBS, Learning and memory, Scopolamine, Amnesia, Elevated plus maze, Novel object recognition test

\section{INTRODUCTION}

Calcium is required for the function of all cells in the body, including neurons. Considerable research has described the function of calcium in the regulation of numerous processes including neurotransmitter release, cytoarchitecture and growth, and activation of enzyme systems including kinases and phosphatases. Calcium is intimately involved in a variety of "plastic" changes in the brain. For example, during adaptive processes such as learning and development, changes in trans-membrane calcium fluxes correlate with changes in neuronal excitability and structural connectivity. Calcium thus is likely to have key roles in the cellular processes underlying aging-related changes in the brain, including normal age-associated memory impairments as well as more severe dementias, including alzheimer's disease. The pivotal role of calcium in so many neuronal processes dictates the need for precise regulation of its intracellular levels. Any dysregulation, however subtle, could lead to dramatic changes in normal neuronal function. Recent studies have implicated altered calcium influx with aging related changes at both the behavioural and the neurophysiological levels. These findings led to 
and continue to support the calcium hypothesis. ${ }^{1,2} \mathrm{~A}$ calcium channel is an ion channel which displays selective permeability to calcium ions. It is sometimes synonymous as voltage-dependent calcium channel, although there is also ligand-gated calcium channels. ${ }^{3}$

Basic research into alzheimer's disease (AD) more than two decades ago demonstrated early and profound loss of cholinergic neurons, a finding that led to the first therapeutic advance with the development and licensing of the first specific treatments: the acetyl cholinesterase inhibitors. Whatever the therapeutic efficiency of these compounds, their impact in the field of dementia care cannot be overestimated. However, today's basic research has the power to go beyond the cholinergic hypothesis, and there is every hope that the current process of fleshing out the bones of the amyloid cascade hypothesis will yield effective disease-modifying treatments. ${ }^{4}$ Calcium channel blockers (CCB), calcium channel antagonists or calcium antagonists are a number of medications that disrupts the movement of calcium $(\mathrm{Ca} 2+)$ through calcium channels. ${ }^{5,6}$ Calcium channel blockers are used as antihypertensive drugs, i.e. as medications to decrease blood pressure in patients with hypertension. CCBs are particularly effective against large vessel stiffness, one of the common causes of elevated systolic blood pressure in elderly patients. Calcium channel blockers are also frequently used to alter heart rate, to prevent cerebral vasospasm, and to reduce chest pain caused by angina pectoris.

Calcium channel blockers are the drugs used in treatment of CVS diseases such as hypertension and angina pectoris. ${ }^{7}$ Usefulness of $\mathrm{CCBs}$ against AD pathology is controversial. Epidemiological studies suggest that CCBs prevent or slow the rate of progression of AD. ${ }^{8-10}$ A large clinical trial with nimodipine did not show significant benefits from the primary outcome measures but has shown moderate benefits for treatment of $\mathrm{AD}$ in the secondary outcome measures. ${ }^{11,12}$ In a recent study, however, nimodipine selectively stimulated the secretion of A $\beta 1-42$ in vitro and in the plasma of Tg2576 mouse model of $\mathrm{AD}$, questioning the usefulness of this $\mathrm{CCB}$ for AD. ${ }^{13,14}$ So this concept became controversial and planned to carry the effectiveness of $\mathrm{CCB}$ on dementia.

Only there are few drugs available to treat dementia (alzheimer's disease). The calcium channel blockers are the category of drugs commonly used to treat hypertension and its influence on dementia is controversial, has lead us investigate the effect of calcium channel blockers against scopolamine induced dementia in Albino rats.

\section{METHODS}

\section{Experimental animals}

Female wistar albino rats weighing $250 \pm 10$ gm were procured from Venkateshwara enterprises Bengaluru. The animals were maintained under standard husbandry conditions (temp $23 \pm 2^{\circ} \mathrm{C}$, relative humidity $55 \pm 10 \%$ and 12 hour light dark cycle). Animals were fed with standard laboratory food and ad libitum during the study period. All animals were used for the study as per CPCSEA guidelines. The whole experiment was approved by IAEC (SKVCP/IAEC/PGCOL/14/06 Dated 19-03-2014)

\section{Drugs, chemicals and its preparation}

Scopolamine $(0.9 \mathrm{mg} / \mathrm{kg})(\text { i.p })^{15}$

Piracetam $(50 \mathrm{mg} / \mathrm{kg})(\mathrm{p} . \mathrm{o})^{16}$

CCB: diltiazem $(10.8 \mathrm{mg} / \mathrm{kg})$, verapamil $(21.6 \mathrm{mg} / \mathrm{kg})$, nimodipine $(0.9 \mathrm{mg} / \mathrm{kg})$ p.o. ${ }^{17}$

The scopolamine hydrobromide dissolved in $0.9 \% \mathrm{NaCl}$. Piracetam, diltiazem, verapamil, and nimodipine were dissolved $0.1 \% \mathrm{CMC}$.

\section{Dose fixation}

The maximum human therapeutic dose all the drugs used in studies was extrapolated to rats based on the body surface area (BSA). ${ }^{18}$

Materials and methods: Dementia was induced by scopolamine. The behavioural changes in the study animals were assessed by behavioural paradigms such as elevated plus maze, and novel object recognition tests and biochemical parameters such as catalase, superoxide dismutase, glutathione peroxidase, malonylaldehyde, protein and AChE.

Animals were divided into ten groups of containing six animals in each group.

Scopolamine hydro bromide was dissolved in an isotonic solution $(0.9 \% \mathrm{NaCl})$ and $0.9 \mathrm{mg} / \mathrm{kg}$ scopolamine was injected i.p. daily for 7 days. ${ }^{19}$ In prophylactic studies animals were treated with piracetam $(50 \mathrm{mg} / \mathrm{kg} /$ day) (p.o), diltiazem (10.8 mg/kg/day) (p.o), verapamil (21.6 $\mathrm{mg} / \mathrm{kg}$ /day) (p.o), and nimodipine (0.9 mg/kg/day) (p.o), half an hour before the administration of scopolamine respectively. In curative studies the animals were injected with scopolamine half an hour later animals were treated with piracetam (50 mg/kg/day) (p.o), diltiazem (10.8 $\mathrm{mg} / \mathrm{kg}$ /day) (p.o), verapamil (21.6 mg/kg/day) (p.o), and nimodipine $(0.9 \mathrm{mg} / \mathrm{kg} / \mathrm{day})$ (p.o), respectively.

\section{Elevated plus-maze test}

The elevated plus maze recently been extended to measure the cognitive performance, notably to evaluate the spatial long term memory in rats. The elevated plus maze, which was introduced by Pellow with rats, consists of two open and two enclosed arms, and is based on the apparent natural aversion of rodents to open and high spaces and is used to measure the anxiety state in 
animals. $^{20,21}$ Animals spend more time in the enclosed arms than the open arms because they dislike the open arms. The aversive quality of the open arm is not apparent until the animals enter them. Based on this parameter it could be demonstrated that transfer latency (the time in which the animal moves from the open arms to the closed arms) will be markedly shortened if the animal had previously experienced entering the open arms, and the increased transfer latency has been shown in cognitive declined condition. Rats were placed individually at end of an open arm facing away from central platform and the time took to move from the end of open arm to either of closed arm (Transfer latency, TL) was recorded. If the animal did not enter into one of the enclosed arms within $90 \mathrm{sec}$, it was gently pushed into one of the two enclosed arms and the TL was assigned as $90 \mathrm{sec}$. The rat was allowed to explore the maze for another $10 \mathrm{sec}$ and then returned to its home cage. Retention of this learned-task was examined 24 hours after the first day trial. Transfer latency after 24 hours was expressed as "inflexion ratio, IR" using the formula $\mathrm{IR}=(\mathrm{L} 1-\mathrm{L} 0) / \mathrm{L} 0$. Where L0 is the transfer latency after 24 hours and L1 is the initial transfer latency in seconds. Rats of either sex, weighing around 150-200 gm, were divided into ten groups consisting of 6 animals each and the drugs were administered as mentioned in Table 1. Orally for 7 days, scopolamine was given intraperitoneally. After $90 \mathrm{~min}$ of administration on 7 th day transfer latency was recorded. Retention of learned task was examined after 24 hours and inflexion ratio was calculated using the following formula.

$\mathrm{IR}=(\mathrm{L} 1 / \mathrm{L} 0) / \mathrm{L} 0 . \mathrm{s}$

Table: 1 Experimental models of dementia: scopolamine induced dementia.

\begin{tabular}{|c|c|c|}
\hline Group no. & Treatment & No. of animals \\
\hline Group - I & Normal control (vehicle $0.1 \%$ CMC for 7 days) & 6 \\
\hline Group - II & Scopolamine $0.9 \mathrm{mg} / \mathrm{kg} / \mathrm{day}$ alone 7 days & 6 \\
\hline Group - III & $\begin{array}{l}\text { Piracetam } 50 \mathrm{mg} / \mathrm{kg} / \mathrm{day} 30 \mathrm{~min} \text { later followed by scopolamine } 0.9 \mathrm{mg} / \mathrm{kg} / \text { day for } \\
7 \text { days (prophylactic studies) }\end{array}$ & 6 \\
\hline Group - VI & $\begin{array}{l}\text { Diltiazem } 10.8 \mathrm{mg} / \mathrm{kg} / \text { day } 30 \mathrm{~min} \text { later followed by scopolamine } 0.9 \mathrm{mg} / \mathrm{kg} / \mathrm{day} \\
\text { for } 7 \text { days (prophylactic studies }\end{array}$ & 6 \\
\hline Group - IV & $\begin{array}{l}\text { Verapamil } 21.6 \mathrm{mg} / \mathrm{kg} / \mathrm{day} 30 \mathrm{~min} \text { later followed by scopolamine } 0.9 \mathrm{mg} / \mathrm{kg} / \mathrm{day} \\
\text { for } 7 \text { days (prophylactic studies }\end{array}$ & 6 \\
\hline Group - V & $\begin{array}{l}\text { Nimodipine } 0.9 \mathrm{mg} / \mathrm{kg} / \mathrm{day} 30 \mathrm{~min} \text { later followed by scopolamine } 0.9 \mathrm{mg} / \mathrm{kg} / \mathrm{day} \\
\text { for } 7 \text { days (prophylactic studies) }\end{array}$ & 6 \\
\hline Group - VII & $\begin{array}{l}\text { Scopolamine } 0.9 \mathrm{mg} / \mathrm{kg} 30 \mathrm{~min} \text { later followed by piracetam } 50 \mathrm{mg} / \mathrm{kg} / \mathrm{day} \text { treated } \\
\text { for7 days.(curative studies) }\end{array}$ & 6 \\
\hline Group - VIII & $\begin{array}{l}\text { Scopolamine } 0.9 \mathrm{mg} / \mathrm{kg} 30 \mathrm{~min} \text { later followed by diltiazem } 10.8 \mathrm{mg} / \mathrm{kg} / \mathrm{day} \text { for } 7 \\
\text { days }\end{array}$ & 6 \\
\hline Group - IX & $\begin{array}{l}\text { Scopolamine } 0.9 \mathrm{mg} / \mathrm{kg} 30 \mathrm{~min} \text { later followed by verapamil } 21.6 \mathrm{mg} / \mathrm{kg} / \mathrm{day} \text { for } 7 \\
\text { days. (curative studies) }\end{array}$ & 6 \\
\hline Group - X & $\begin{array}{l}\text { Scopolamine } 0.9 \mathrm{mg} / \mathrm{kg} 30 \mathrm{~min} \text { later followed by nimodipine } 0.9 \mathrm{mg} / \mathrm{kg} / \mathrm{day} \text { for } 7 \\
\text { days. (curative studies) }\end{array}$ & 6 \\
\hline Total & & 60 \\
\hline
\end{tabular}

\section{Novel object recognition (NOR)}

To examine the factors driving exploration, curiosity and reaction to novel stimuli, is an experimental paradigm commonly known as novel object recognition (NOR) or novel object preference (NOP). The novel object recognition test can be evaluated by the differences in the exploration time of novel and familiar objects. Its application is not limited to a field of research and enables that various issues can be studied, such as the memory and learning, the preference for novelty, the influence of different brain regions in the process of recognition, and even the study of different drugs and their effect. ${ }^{22,23}$
The studies have employed NOR to examine differences in memory and reaction to novelty, in various reminder treatments. ${ }^{24,25}$ Curiosity and basic exploratory responses are key components to the behavioural repertoires of the most animal species, and thus a thorough and complete understanding of these issues is vital. Simply put, I am curious about curiosity. The essential role it plays in the everyday lives of both humans and non-human animals is undeniable.

\section{Novel object recognition procedures}

The open field apparatus consisting of colored plywood $(70 \times 60 \times 30 \mathrm{~cm})$. The objects to be discriminated were placed at diagonally opposite corners of the box. On the 
day of test in the first trial (T1), two identical objects were presented in two opposite corners of the box and the amount of time taken by each rat to complete $20 \mathrm{sec}$ explorations was measured. Exploration meant directing the nose at a distance less than $2 \mathrm{~cm}$ to the object and/or touching with the nose (589). During the second trial (T2, 90 min after T1) a new object replaced one of the object presented during T1 and time spent for exploring new $(\mathrm{N})$ and familiar (F) objects was recorded. This procedure carried on animals before administering the drugs (pretrail) as well after completing drug administration (posttrail). The Discrimination index $(\mathrm{DI})=(\mathrm{N}-\mathrm{F}) /(\mathrm{N}+\mathrm{F}){ }^{26-28}$

After completing behavioural paradigms, the animals were fasted for 18 hours. After 24 hours of drug treatment the animals were scarified by cervical dislocation, brains were removed. Each brain was separately put on ice and rinsed with ice-cold isotonic saline. A $(10 \% \mathrm{w} / \mathrm{v})$ homogenate was prepared in $0.1 \mathrm{M}$ phosphate buffer (pH 7.4). The homogenate was centrifuged at $3000 \mathrm{rpm}$ for 15 minutes and aliquots of supernatant were separated and used for biochemical parameters estimation. $^{29}$

\section{Biochemical parameters}

An antioxidant is a molecule capable of inhibiting the oxidation of other molecules. Oxidation is a chemical reaction that transfers electrons from a substance to an oxidizing agent. Oxidation reactions can produce free radicals. In turn, these radicals can start chain reactions that damage cells. Antioxidants terminate these chain reactions by removing free radical intermediates and inhibit other oxidation reactions.

Although oxidation reactions are crucial for life, they can also be damaging; hence, plants and animals maintain complex systems of multiple types of antioxidants, such as glutathione, vitamin $\mathrm{C}$, and vitamin $\mathrm{E}$ as well as enzymes such as catalase, superoxide dismutase glutathione peroxidase. In the present study the biochemical parameters such as SOD, CAT, GPx and MDA, oxidized protein are estimated as an index of antioxidant status and oxidative stress respectively. AChE was estimated to evaluate cholinergic function.

\section{Malonylaldehyde (MDA)}

Oxygen derived free radicals react with membrane lipids to form lipid peroxides and malondialdehyde (MDA) which is the end product of lipid peroxidation. Reactive oxygen species degrade polyunsaturated lipids, forming malondialdehyde. This compound is a reactive aldehyde and is one of the many reactive electrophile species that cause toxic stress in cells and form covalent protein adducts referred to as advanced lipoxidation end-products (ALE), in analogy to advanced glycation end-products (AGE). ${ }^{30}$ The production of this aldehyde is used as a biomarker to measure the level of oxidative stress in an organism.

\section{Thiobarbituric acid reactive substances (TBARS) assay}

This assay is used to determine the lipid peroxidation. Aliquots of $0.5 \mathrm{~mL}$ distilled water were added with $1 \mathrm{~mL}$ of $10 \%$ trichloroacetic acid and were added with $0.5 \mathrm{~mL}$ of brain tissue homogenate.

This was centrifuged at $3000 \mathrm{rpm}$ for $10 \mathrm{~min}$. To the $0.2 \mathrm{~mL}$ supernatant, $0.1 \mathrm{~mL}$ thiobarbituric acid $(0.375 \%)$ was added.

Total solution is placed in water bath at $80^{\circ} \mathrm{C}$ for $40 \mathrm{~min}$ and cooled at room temperature. Absorbance was read at $532 \mathrm{~nm}^{31,32}$

\section{Catalase}

Catalase is a common enzyme found in living organisms. Its function includes catalysing the decomposition of hydrogen peroxide to water and oxygen.

Removal of the $\mathrm{H}_{2} \mathrm{O}_{2}$ from the cell by catalase provides protection against oxidative damage to the cell. It's role in oxidative stress related diseases has been widely studied. $^{33}$

\section{Principle}

Catalase measurement was carried out by the ability of CAT to oxidize hydrogen peroxide $\left(\mathrm{H}_{2} \mathrm{O}_{2}\right)$. Decomposition of $\mathrm{H}_{2} \mathrm{O}_{2}$ gives water and oxygen.

The visible light absorption of hydrogen peroxide solution can be easily measured between 420 to $600 \mathrm{~nm}$. On decomposition of hydrogen peroxide by catalase, the absorption decreases with time. The enzyme activity could be arrived at this decrease.

\section{Procedure}

The reaction mixture consisted of $150 \mu 1$ phosphate buffer (0.01 M pH 7.0), $100 \mu \mathrm{l}$ supernatant. Reaction was started by adding $250 \mu 1 \mathrm{H}_{2} \mathrm{O}_{2} 0.16 \mathrm{M}$, incubated at $37^{\circ} \mathrm{C}$ for $1 \mathrm{~min}$ and reaction was stopped by addition of $1 \mathrm{ml}$ of dichromate: acetic acid reagent. They were immediately kept in a boiling water bath for $15 \mathrm{~min}$ and the green colour developed during the reaction was read at $570 \mathrm{~nm}$ on a spectrophotometer. Control tubes, devoid of enzyme, were also processed in parallel. The enzyme activity is expressed as mol of $\mathrm{H}_{2} \mathrm{O}_{2}$ consumed/min/mg protein. ${ }^{34-36}$

\section{Assay of glutathione peroxidase}

To $0.4 \mathrm{ml}$ of buffer, $0.2 \mathrm{ml}$ of EDTA, $0.1 \mathrm{ml}$ of sodium azide, $0.2 \mathrm{ml}$ of reduced glutathione and $0.1 \mathrm{ml}$ of $\mathrm{H} 2 \mathrm{O} 2$ were added to two test tubes labeled as test (T) and control (C). To the test, $0.2 \mathrm{ml}$ of sample and to the control added $0.2 \mathrm{ml}$ of water was added. The contents were mixed well and incubated at $37^{\circ} \mathrm{C}$ for 10 minutes. The reaction was arrested with the addition of $0.5 \mathrm{ml}$ of 
10\% TCA. To determine the glutathione content, $1.0 \mathrm{ml}$ of supernatant was removed by centrifugation. To that added, $3.0 \mathrm{ml}$ of buffer and $0.5 \mathrm{ml}$ of Ellman's reagent were added. The colour developed was read at 412 $\mathrm{nm}^{37,38}$

\section{Superoxide dismutase $(\text { SOD })^{39-43}$}

\section{Principle}

The method involves generation of superoxide radical of riboflavin and its detection by nitrite formation from hydroxylamine hydrochloride. The nitrite reacts with sulphanilic acid to produce a diazonium compound which subsequently reacts with naphthylamine to produce a red azo compound whose absorbance is measured at $543 \mathrm{~nm}$.

\section{Proteins}

Estimation of proteins by Bradford method. ${ }^{44}$

\section{Principle}

The protein in solution can be measured quantitatively by different methods. The methods described by Bradford uses a different concept-the protein's capacity to bind to a dye, quantitatively. The assay is based on the ability of proteins to bind to coomassie brilliant blue and form a complex whose extinction coefficient is much greater than that of free dye.

\section{Acetylcholinesterase}

Assay of acetylcholinesterase activity in the brain. ${ }^{45-47}$
The method of AChE activity estimation is popularly known as Ellman's method named after George Ellman who developed this method in 1961.

\section{Principle}

A photometric method for determining acetylcholinesterase activity of tissue homogenates. The enzyme activity is measured by providing an artificial substrate, acetylthiocholine (ATC). Thiocholine released because of the cleavage of ATC by AChE is allowed to react with the $-\mathrm{SH}$ reagent 5, 5'-dithiobis-(2-nitrobenzoic acid) (DTNB), which is reduced to thionitrobenzoic acid, a yellow coloured anion with an absorption maxima at $412 \mathrm{~nm}$.

\section{Statistical analysis}

The values were expressed as Mean \pm SEM. Statistical analysis was performed by one way analysis of variance (ANOVA) followed by Dunnett multiple comparison tests using the demo version of Graphpad Instat 3.0 software. $\mathrm{P}$ values $<0.05$ were considered as significant.

\section{RESULTS}

\section{Scopolamine induced dementia}

\section{Behavioural paradigms}

The effect of the different types of calcium channel blockers on scopolamine induced dementia was studied by using memory models such as elevated plus maze test and novel object recognition test.

Table 2: The effect of CCB on inflexion ratio in elevated plus maze test against scopolamine induced dementia model in rats.

\begin{tabular}{|llll|}
\hline \multirow{2}{*}{ Groups } & Treatment & Inflexion ratio $=$ & Post-trail \\
\hline I & Vehicle control & Pre-trail & $2.038 \pm 0.4746$ \\
\hline II & Disease control & $1.94 \pm 0.364$ & $0.56 \pm 0.309$ \\
\hline III & Prophylactic - piracetam control & $1.99 \pm 0.1514$ & $1.20 \pm 0.281 \mathrm{~ns}$ \\
\hline IV & Prophylactic - diltiazem control & $1.12 \pm 0.174 \mathrm{~ns}$ & $1.26 \pm 0.1890^{* *}$ \\
\hline V & Prophylactic - verapamil control & $1.03 \pm 0.333^{*}$ & $1.09 \pm 0.23^{*}$ \\
\hline VI & Prophylactic -nimodipine control & $1.0 \pm 0.215^{*}$ & $1.02 \pm 0.19^{*}$ \\
\hline VII & Curative - piracetam control & $1.6 \pm 0.15 \mathrm{~ns}$ & $1.67 \pm 0.025^{*}$ \\
\hline VIII & Curative - diltiazem control & $1.01 \pm 0.48^{*}$ & $1.09 \pm 0.187^{* *}$ \\
\hline IX & Curative - verapamil control & $1.06 \pm 0.149^{*}$ & $1.29 \pm 0.149^{* *}$ \\
\hline $\mathbf{X}$ & Curative -nimodipine control & $1.17 \pm 0.242 \mathrm{~ns}$ & $0.99 \pm 0.242^{* *}$ \\
\hline
\end{tabular}

Values are mean \pm SEM $(n=6)$ one way ANOVA followed by Dunnett test; Significance value = Comparison with vehicle control group animals; $* \mathrm{p}<0.05$ represents significant; $* * \mathrm{p}<0.01$ represents, highly significant and; $* * * \mathrm{p}<0.001$ represents very significant; ns-no significance. 


\section{Elevated plus maze test}

From Table 2 it was found that the inflexion ratio of animals in elevated plus maze was high in vehicle control, followed by piracetam, diltiazem, verapamil and nimodipine in prophylactic studies respectively when compared to the disease control. Where as in curative studies in the order of piracetam $\geq$ diltiazem $\geq$ verapamil $\geq$ nimodipine were better when compared to the disease control. The treated groups have shown decrease in transfer latencies leading to increase in inflexion ratios when compared to disease control. The results are tabulated in Table 2 and Figure 1.

\section{Novel object recognition}

From Table 3 it was found that the discrimination index (DI) was reduced in scopolamine treated group when compared to vehicle control treatment. It was also observed that in both prophylactic and curative studies with CCB viz diltiazem, verapamil, nimodipine showed increased DI when compared to scopolamine treated group and was comparable to that of vehicle control group animals.

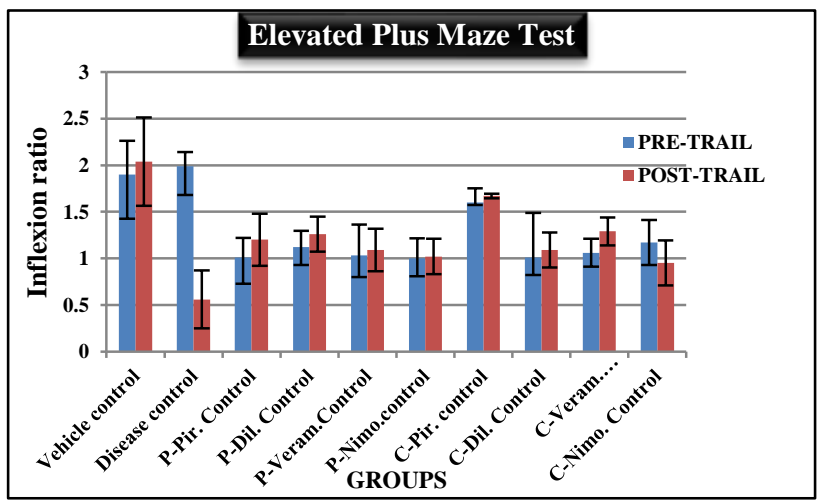

Figure 1: Effect of calcium channel blockers on elevated plus maze test.

Table 3: TCVHE effect of CCB on discrimination index in novel object recognition test against scopolamine induced dementia model in rats.

\begin{tabular}{|llll|}
\hline Groups & Treatment & Discrimination index (Mean \pm SEM) \\
\hline I & & Pre - trail & Post - trail \\
\hline II & Vehicle control & $0.38 \pm 0.096$ & $0.36 \pm 0.083$ \\
\hline III & Disease control & $0.26 \pm 0.0143$ & $0.12 \pm 0.165$ \\
\hline IV & Prophylactic - piracetam control & $0.34 \pm 0.049 \mathrm{~ns}$ & $0.48 \pm 0.014^{* *}$ \\
\hline V & Prophylactic - diltiazem control & $0.358 \pm 0.062 \mathrm{~ns}$ & $0.36 \pm 0.123 \mathrm{~ns}$ \\
\hline VI & Prophylactic -verapamil control & $0.278 \pm 0.08 \mathrm{~ns}$ & $0.446 \pm 0.069^{*}$ \\
\hline VII & Curative - piracetam control & $0.336 \pm 0.099 \mathrm{~ns}$ & $0.419 \pm 0.088^{*}$ \\
\hline VIII & Curative -diltiazem control & $0.363 \pm 0.095 \mathrm{~ns}$ & $0.46 \pm 0.092^{*}$ \\
\hline IX & Curative -verapamil control & $0.33 \pm 0.087 \mathrm{~ns}$ & $0.40 \pm 0.0201^{*}$ \\
\hline $\mathbf{X}$ & Curative -nimodipine control & $0.32 \pm 0.012^{*}$ & $0.39 \pm 0.015^{*}$ \\
\hline Value & P & $0.353 \pm 0.06 \mathrm{~ns}$ & $0.39 \pm 0.069^{*}$ \\
\hline
\end{tabular}

Values are mean \pm SEM $(n=6)$ one way ANOVA followed by Dunnett test; Significance value = Comparison with vehicle control group animals; ${ }^{*} \mathrm{p}<0.05$ represents significant; ${ }^{* *} \mathrm{p}<0.01$ represents, highly significant and; ***p $<0.001$ represents very significant; ns-no significance

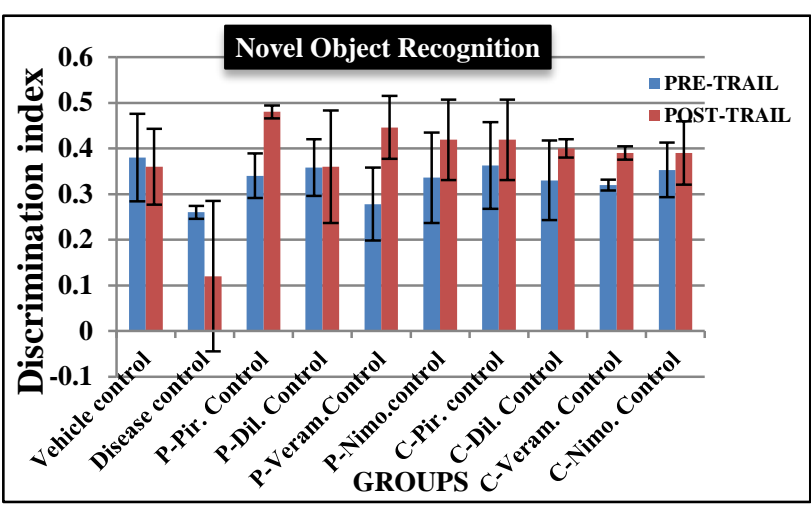

Figure 2: Effect of calcium channel blockers on novel object recognition test.
The DI of animals in novel object recognition test was high in post-trail when compared to pre-trail. The results are given in Table 3 and Figure 2.

\section{Biochemical parameters}

From the Table 4 and, 5 and Figure 3, 4, 5, 6, 7, and 8 it was found that in scopolamine induced dementia model the disease control rats showed decreased levels of antioxidant enzymes CAT, SOD, and GPx in the brain tissue indicating the damage due the generation of ROS. The lipid peroxidation end product MDA levels was also elevated in scopolamine treated group when compared to vehicle control. 


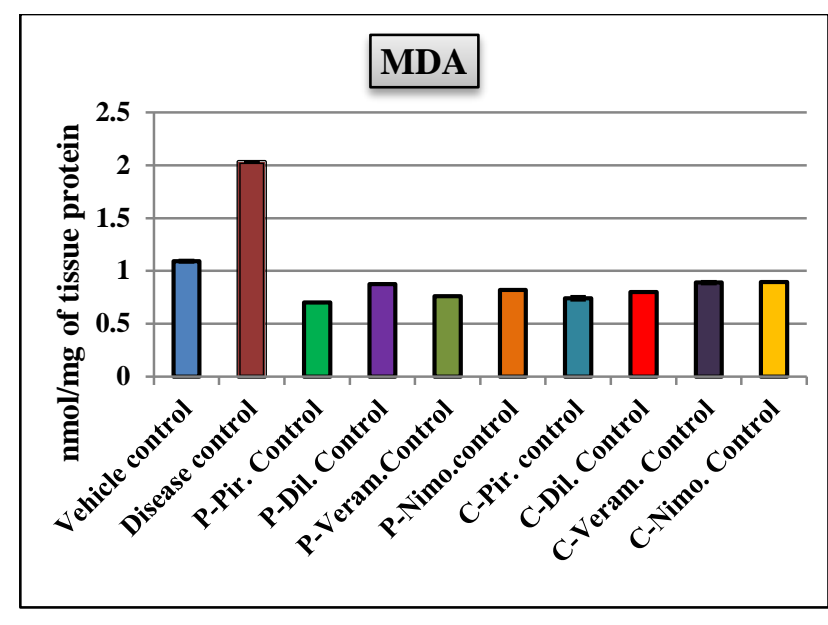

Figure 3: The effect of CCB on tissue MDA levels in scopolamine.
The AChE level increased significantly in scopolamine treated group when compared to vehicle control. Even the oxidized protein levels also significantly elevated in scopolamine treated group when compared to the vehicle control group. The animals treated with diltiazem, verapamil, and nimodipine showed significant changes in the above said parameters.

The brain tissue enzymes SOD, CAT, and GPx levels were significantly elevated in CCB treated group when compared to disease control group. The brain tissue protein, AChE, and MDA levels were significantly decreased in CCB treated group. Treated group when compared to disease control group, but the levels were failed to reach the standard drug piracetam. In prophylactic studies it was observed that verapamil offered significant protection followed by nimodipine and diltiazem. The curative study revealed that the diltiazem offered better protection than the verapamil and nimodipine.

Table 4: The effect of CCB on tissue MDA, CAT and GPx levels in scopolamine induced dementia in rats.

\begin{tabular}{|lllll|}
\hline Groups & Treatment & $\begin{array}{l}\text { MDA (nmol/mg of } \\
\text { tissue protein) }\end{array}$ & $\begin{array}{l}\text { CAT }\left(\mathrm{mol} \text { of } \mathrm{H}_{2} \mathrm{O}_{2}\right. \\
\text { consumed/min/mg of } \\
\text { tissue protein) }\end{array}$ & $\begin{array}{l}\mathrm{GPx}(\boldsymbol{\mu g} \text { of } \\
\text { glu.consumed/min } / \mathrm{mg} \\
\text { of tissue protein) }\end{array}$ \\
\hline I & Vehicle control & $0.3083 \pm 0.004$ & $0.85 \pm 0.0036$ & $0.027 \pm 0.0021$ \\
\hline II & Disease control & $0.495 \pm 0.0138$ & $0.648 \pm 0.047 * *$ & $0.0116 \pm 0.0016 \mathrm{~ns}$ \\
\hline III & Prophylactic- piracetam control & $0.183 \pm 0.0263^{* *}$ & $0.808 \pm 0.015^{* *}$ & $0.033 \pm 0.00210^{* *}$ \\
\hline IV & Prophylactic- diltiazem control & $0.22 \pm 0.008^{* *}$ & $0.648 \pm 0.039 * *$ & $0.0286 \pm 0.0016 \mathrm{~ns}$ \\
\hline V & Prophylactic-verapamil control & $0.206 \pm 0.013^{*}$ & $1.065 \pm 0.0125^{* *}$ & $0.031 \pm 0.0042^{* *}$ \\
\hline VI & Prophylactic-nimodipine control & $0.226 \pm 0.005^{* *}$ & $0.976 \pm 0.0071^{* *}$ & $0.0276 \pm 0.0016 \mathrm{~ns}$ \\
\hline VII & Curative- piracetam control & $0.26 \pm 0.030^{* *}$ & $0.725 \pm 0.0070^{* *}$ & $0.029 \pm 0.0022^{*}$ \\
\hline VIII & Curative-diltiazem control & $0.21 \pm 0.0050^{* *}$ & $0.823 \pm 0.0091 \mathrm{~ns}$ & $0.033 \pm 0.0021^{* *}$ \\
\hline IX & Curative-verapamil control & $0.23 \pm 0.015 *$ & $0.67 \pm 0.0047 *$ & $0.028 \pm 0.0016 \mathrm{~ns}$ \\
\hline X & Curative-nimodipine control & $0.331 \pm 0.006^{* *}$ & $0.74 \pm 0.006 * *$ & $0.0306 \pm 0.0025^{* *}$ \\
\hline
\end{tabular}

Values are mean \pm SEM $(n=6)$ one way ANOVA followed by Dunnett test; Significance value $=$ Comparison with vehicle control group animals; $* \mathrm{p}<0.05$ represents significant; $* * \mathrm{p}<0.01$ represents, highly significant and; $* * * \mathrm{p}<0.001$ represents very significant; ns-no significance

Table 5: The effect of CCB on tissue SOD, Protein and AChE levels in scopolamine induced dementia in rats.

\begin{tabular}{|lllll|} 
Groups & Treatment & $\begin{array}{l}\text { SOD (nmol/mg of } \\
\text { tissue protein) }\end{array}$ & $\begin{array}{l}\text { Protein }(\mathrm{mg} / \mathrm{g} \text { of } \\
\text { tissue tissue) }\end{array}$ & $\begin{array}{l}\text { AChE } \\
(\boldsymbol{\mu m o l} / \mathrm{min} / \mathrm{mg} \text { of } \\
\text { tissue protein) }\end{array}$ \\
\hline I & Vehicle control & $0.285 \pm 0.0140$ & $1.091 \pm 0.0113$ & $0.27 \pm 0.014$ \\
\hline II & Disease control & $0.17 \pm 0.0304$ & $2.03 \pm 0.0016$ & $0.48 \pm 0.025$ \\
\hline III & Prophylactic- piracetam control & $0.47 \pm 0.00936^{* *}$ & $0.7016 \pm 0.0016^{* *}$ & $0.14 \pm 0.039 * *$ \\
\hline IV & Prophylactic- diltiazem control & $0.36 \pm 0.0049 * *$ & $0.876 \pm 0.0021^{*}$ & $0.16 \pm 0.043^{* *}$ \\
\hline V & Prophylactic-verapamil control & $0.29 \pm 0.1120^{*}$ & $0.76 \pm 0.0021^{* *}$ & $0.15 \pm 0.040^{*}$ \\
\hline VI & Prophylactic-nimodipine control & $0.373 \pm 0.0095^{* *}$ & $0.82 \pm 0.002^{*}$ & $0.15 \pm 0.015^{* *}$ \\
\hline VII & Curative- piracetam control & $0.403 \pm 0.0071 * *$ & $0.74 \pm 0.020^{* *}$ & $0.10 \pm 0.014 * *$ \\
\hline VIII & Curative-diltiazem control & $0.3516 \pm 0.0060^{* *}$ & $0.80 \pm 0.0033^{*}$ & $0.17 \pm 0.0160^{* *}$ \\
\hline IX & Curative-verapamil control & $0.28 \pm 0.0063 \mathrm{~ns}$ & $0.89 \pm 0.01493^{*}$ & $0.19 \pm 0.040^{*}$ \\
\hline X & Curative-nimodipine control & $0.3216 \pm 0.0047 *$ & $0.895 \pm 0.0056^{*}$ & $0.21 \pm 0.0395 \mathrm{~ns}$ \\
\hline
\end{tabular}

Values are mean \pm SEM $(n=6)$ one way ANOVA followed by Dunnett test; Significance value = Comparison with vehicle control group animals; ${ }^{*} \mathrm{p}<0.05$ represents significant; $* * \mathrm{p}<0.01$ represents, highly significant and; $* * * \mathrm{p}<0.001$ represents very significant; ns-no significance 


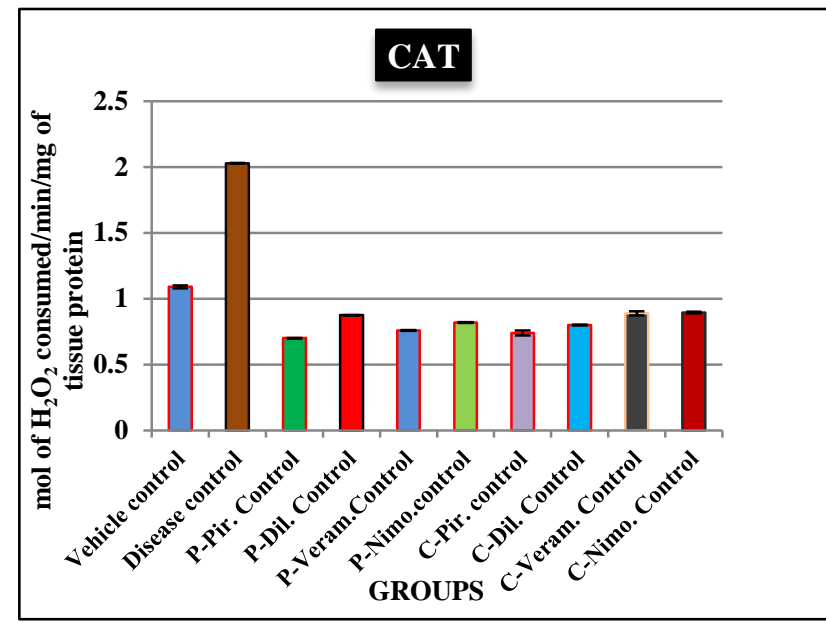

Figure 4: The effect of CCB on tissue CAT levels in scopolamine induced dementia in rat.

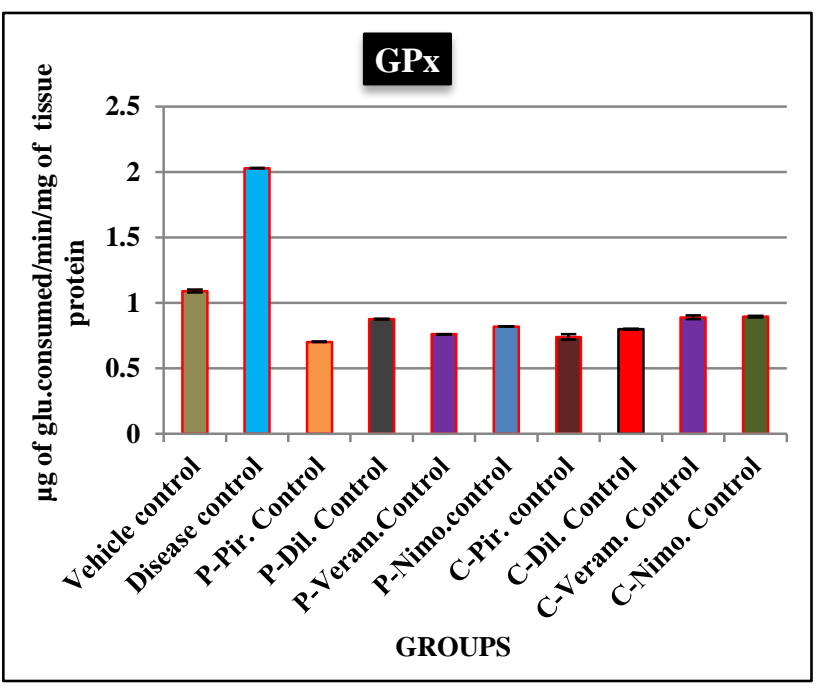

Figure 5: The effect of CCB on tissue GPx levels in scopolamine induced dementia in rats.

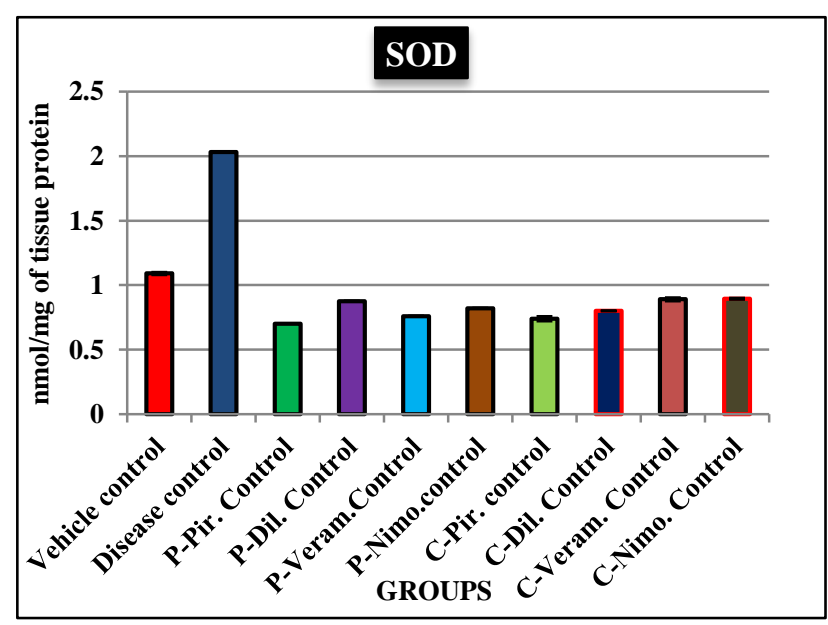

Figure 6: The effect of CCB on tissue SOD levels in scopolamine induced dementia in rats.

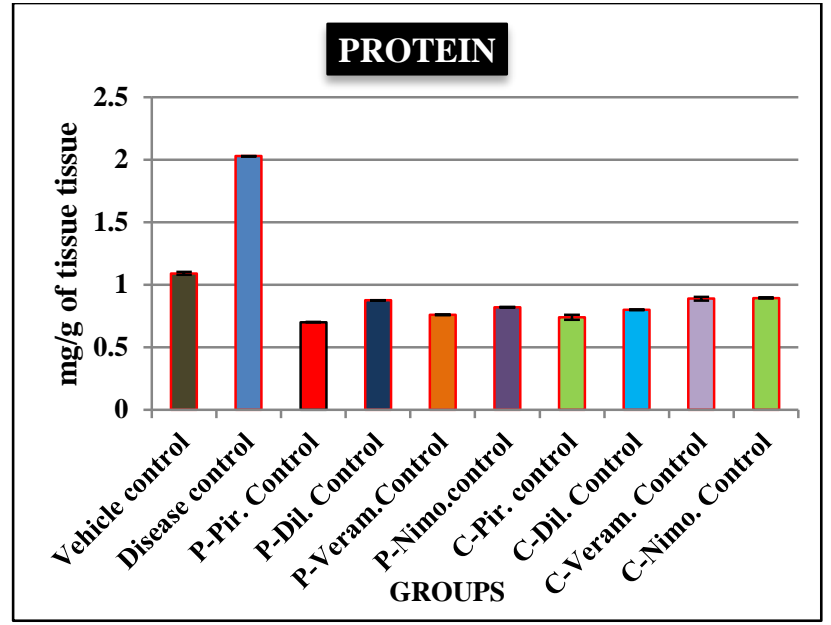

Figure 7: The effect of CCB on tissue protein levels in scopolamine induced dementia in rats.

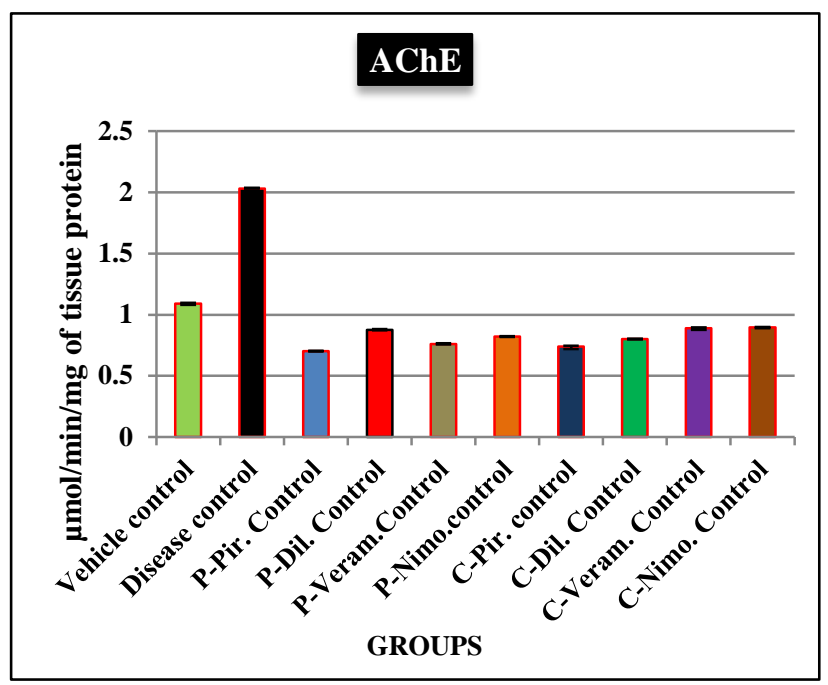

Figure 8: The effect of $\mathrm{CCB}$ on tissue $\mathrm{AChE}$ levels in scopolamine induced dementia in rats.

\section{DISCUSSION}

Alzheimer's disease (AD) is a brain disorder named by German physician Aloes Alzheimer, who first described it in 1906. $\mathrm{AD}$ is progressive and neurodegenerative diseases that primarily affect the elderly population of over 65 years of age, and are estimated to account for 50 $60 \%$ of the dementia cases. ${ }^{48}$ People with Alzheimer's also have trouble with visual-spatial areas, reasoning, judgment, and insight. Memory impairment is the hallmark symptom of Alzheimer's disease. The part of the brain most affected by Alzheimer's is the hippocampus. The hippocampus plays a central role to form new episodic memory in various species including humans. ${ }^{49}$

Learning may be described as the mechanism by which new information about the world is acquired, and memory as the mechanism by which that knowledge is retained. It is convenient to categorized memory as being explicit, 
which is defined as that involved in the conscious recall of information about people, places and things, or implicit, which is categorized by non-conscious recall of tasks such as motor skills. Explicit memory depends on the integrity of temporal lobe and diencephalic structures such as hippocampus, subiculum, and entorhinal cortex. Implicit memory includes simple associative forms of memory, such as habituation and relies of integrity of cerebellum and basal ganglia. ${ }^{50}$

The present study reveals the effect of $\mathrm{CCB}$ on experimentally induced dementia by scopolamine. Therefore it is very much clear that calcium plays a vital role in the brain and responsible for various types of neurodegerative disorders. Calcium channel blockers are widely used in the treatment of various types of CVS disorders and aliments. The role of CCB in dementia is not clearly understood. There are numerous reports indicating that, they would facilitate learning and memory. ${ }^{51-53}$ and on the other hand there are reports claiming that they impair memory. ${ }^{54-56}$ Hence the effect of CCBS on memory and learning is controversial.

The pathogenesis of $\mathrm{AD}$ is multifactorial and includes degeneration of cholinergic neurons, abnormal phosphorylation of the protein tau, oxidative stress, exitotoxicity and altered protein processing resulting in abnormal $\beta$-amyloid peptide $(\mathrm{A} \beta)$ accumulation and increased blood glucose level which may be due to decreased pyruvate formation that affects the synthesis of acetylcholine extracellular aggregates of amyloid- $\beta$ (A $\beta)$ peptide (amyloid plaques), neurofibrillary tangles and synaptic loss. ${ }^{58}$ According to the amyloid cascade hypothesis, overproduction of the hydrophobic peptide $A \beta 1-42$ is the basis for AD pathology. Aggregation of $\mathrm{A} \beta 1-42$ is thought to occur in several steps via fibrils, which are finally deposited as amyloid plaques.

\section{Calcium signalling, excitotoxicity and $A D$}

Calcium is a principal intracellular messenger mediating responses to electrical and chemical stimulation. Maintenance of the precise intracellular calcium homoeostasis is fundamental to neuronal viability and functioning. During aging, the control of the intracellular calcium concentration is impaired, leading to neuronal dysfunction. ${ }^{59}$ In $\mathrm{AD}, \mathrm{A} \beta$ induces influx of extracellular calcium, and clinical mutations in the presenilin gene cause calcium release from the endoplasmatic reticulum. Changes in calcium influx across different cellular membranes may lead to neuropathology and cell death. ${ }^{60}$ At presynaptic terminals, voltage-gated calcium channels (VGCCs) ( $\mathrm{N}$ and $\mathrm{P} / \mathrm{Q}$ types) mediate the release of neurotransmitter upon arrival of action potentials. A release of glutamate at central synapses facilitates calcium entry at postsynaptic sites through NMDA receptors and indirectly through L-type calcium channels. ${ }^{61}$ Excessive glutamate release leads to an imbalance of the postsynaptic calcium load, triggering intracellular cascades that finally cause neuronal death. This process, termed 'excitotoxicity', has been proposed to underlie the pathology of a variety of neurodegenerative disorders, including $\mathrm{AD}{ }^{62}$ Excitotoxicity can be attenuated by blocking calcium influx in both synaptic terminals as well as postsynaptic sites. A number of proteins are modulated by $\mathrm{A} \beta$, and some of them contribute to the cellular calcium regulation (e.g. VGCCs, the NMDA receptor and the calcium activated protease calpain). All the calcium channel blockers are potent vasodilators, and their functional effect provides the rationale for their use in the treatment of various cardiovascular and neurological conditions. $^{63}$

The important role of L-type VDCC in learning and memory is due to their involvement on the synaptic plasticity (i.e., the long lasting LTP) of hippocampal dentate CA1 field, which considers being one possible cellular mechanism underlying cognition. ${ }^{64}$ In vivo and in vitro electrophysiological recording of hippocampal neuron function have demonstrated the presence of L-type VDCCs, and activity-dependent $\mathrm{Ca} 2+$ entry into neurons to initiate LTP in this region has been described. ${ }^{65}$

Administration of scopolamine to rats led to a decrease in reduced glutathione (GSH) levels in the hippocampus indicating generation of oxidative stress. Our results were consistent with these data as injection of scopolamine produced a significant increase in lipid peroxide level expressed as MDA, oxidized protein and $\mathrm{AChE}$ and as well as attenuation of SOD, GPX and CAT activities in rat brains compared to vehicle control rats. ${ }^{66}$

$\mathrm{AChE}$ is the ACh metabolizing enzyme estimated to evaluate cholinergic function indirectly, the AChE levels are elevated with scopolamine indicates reduced ACh, and inversely the $\mathrm{AChE}$ levels are decreased with treatment of CCB indicates the ACh levels are increased.

Our results showed that $\mathrm{CCB}$ significantly enhanced the SOD, CAT and GPx activities that were attenuated by scopolamine. On the other hand, CCB markedly reduced the elevated lipid peroxide levels, MDA, oxidized protein and $\mathrm{AChE}$ that were augmented by scopolamine administration. The learning and memory with CCB was accompanied by a significant elevation of IR and DI in elevated plus maze test and novel object recognition test respectively. Our results are in agreement with the findings that CCB produced a marked improvement in both learning and memory, and oxidative stress markers that were deteriorated by scopolamine induced dementia in rats. ${ }^{67}$

The mechanism responsible for $\mathrm{CCB}$ protective effect against scopolamine induced dementia in our studies might be due to relative reduction of cellular calcium influx via its effect on the slow L-type calcium channel. There is involvement of calcium in triggering oxidative damage and excitotoxicity, both of which play central role in scopolamine induced dementia and associated alterations. $^{68}$ Accordingly, reduction of intracellular 
calcium concentrations by $\mathrm{CCB}$ may reduce free radical generating mechanisms and lipid peroxidation. ${ }^{69} \mathrm{~A}$ reasonable concept is that calcium overload enhances the formation of oxygen-derived free radicals and lipid peroxidation. Thus the beneficial action of CCB for prevention of oxidative damage may be twofold: first prevention of cytosolic calcium overload and second inhibition of the toxic effects of oxygen-derived free radicals. There are reports indicating the potent antioxidant activity of CCB against lipid auto peroxidation and it was found to be nifedipine has the most potent antioxidant activity. ${ }^{70}$

The neuroprotective activity of the CCBs in central nervous system was biphasic; increasing concentrations resulted in a decrement of neuroprotection. This suggests that there is a favourable balance in the amount of calcium that is required for the survival of CGCs (cultured cerebral granule cells) and that a deficiency in intracellular calcium may compromise normal function and ultimately promote cytotoxicity. ${ }^{71}$

Another possible mechanism involved in neuroprotective property with $\mathrm{CCB}$, by acting nAChRs (neuronal nicotinic cholinergic receptors). Neuronal nicotinic cholinergic receptors (nAChRs) form a heterogeneous family of ligand-gated ion channels found in the central and peripheral nervous system that regulate synaptic activity. $^{72}$ Numerous subtypes of nAChRs have been identified and many of them were recognized to be involved in specific neurological and physiological behaviors. For instance, $\alpha 3 \beta 2 \mathrm{nAChR}$ plays a role in dopamine release and Parkinson's disease, $\alpha 3 \beta 4$ regulates noradrenaline release and cardiovascular or gastrointestinal action, and $\alpha 9$ was found important in development of auditory functions. Moreover, the most abundant subtypes of the nAChRs in the cortex, i.e., $\alpha 4 \beta 2, \alpha 4 \beta 4$, and $\alpha 7$ are involved in memory, learning, and sensory gating functions. ${ }^{73}$

nAChRs are activated by endogenous acetylcholine (ACh) and the group of ortosteric agonists, such as nicotine, while their activity is inhibited by a diverse group of competitive antagonists. Except for these actions, different subtypes of nAChR can be modulated allosterically by various endogenous [e.g., substance P, serotonin (5-HT), fatty acids, steroids or $\beta$-amyloid] as well as exogenous (e.g., alkaloids, venom toxins, alcohol, and other drugs) substances with different binding sites on the nAChRs. ${ }^{74}$ In fact, over 50 marketed drugs belonging to different therapeutic classes exert allosteric positive (noncompetitive agonists) or allosteric negative (noncompetitive antagonists) modulation on nAChRs, and many of these actions are subtype specific. CCBs can be strong noncompetitive inhibitors for the $\alpha 3 \beta 4$ subtype of nAChRs. ${ }^{75}$

Our data extend the present knowledge about the influence of pharmacological blockade of L-type VDCC on memory and learning processes in the context of possible interactions with cholinergic transmission and oxidative stress markers.

However further studies are required to confirm the neuroprotective activity of CCBs in AD. Studies also have to be extended to find out why verapamil was good in prophylactic studies and diltiazem in curative studies.

The beneficial effects showed by CCBs in AD might be by acting as a agonist of nAChRs and reduction of intracellular calcium concentrations, reducing free radical generating mechanisms and lipid peroxidation, however further studies are warranted to find out the exact mechanism through which $\mathrm{CCB}$ showing the protective activity in AD.

\section{CONCLUSION}

The present investigation reveals the cognitive enhancement effect of different calcium channel blockers tried in the studies. It was also revealed that in prophylactic studies verapamil was found to be better and diltiazem in curative studies among the different types of calcium channel blockers studied in these experiment. The calcium channel blockers also protected the brain tissue from scopolamine induced oxidative stress which was reflected by the various brain tissue and serum biomarkers estimated in these study.

\section{Funding: No funding sources \\ Conflict of interest: None declared \\ Ethical approval: The study was approved by the Institutional Ethics Committee}

\section{REFERENCES}

1. Striggow F, Ehrlich BE. Ligand-gated calcium channels inside and out. Curr Opin Cell Biol. 1996;8(4):490-5.

2. Hardy JA, Higgins GA. Alzheimer's disease: the amyloid cascade hypothesis. Science. 1992;256:1845 .

3. Abernethy DR, Schwartz JB. Ca2+-antagonist drugs. N Engl J Med. 1999;341:1447-57.

4. Betkowski AS, Hauptman PJ. Update on recent clinical trials in congestive heart failure. Curr Opin Cardiol. 2000;15:293-303.

5. Cutler JA. Ca2+-channel blockers for hypertension-uncertainty continues. N Engl J Med. 1998;338:67981.

6. American Heart Association. 1999 heart and stroke statical update. Dallas, Texes: American Heart Asssociation; 2000.

7. Forette F, Seux ML, Staessen JA, Thijs L, Birkenhager WH, Babarskiene MR, et al. Prevention of dementia in randomised double-blind placebocontrolled systolic hypertension in Europe (Syst-Eur) trial. Lancet. 1998;352:1347-51. 
8. Fritze J, Walden J. Clinical findings with nimodipine in dementia: test of the calcium hypothesis. J Neural Transm Suppl. 1995;46:439-53.

9. Tollefson GD. Short-term effects of the calcium channel blocker nimodipine (Bay-e-9736) in the management of primary degenerative dementia. Biol Psychiatry. 1990;27:1133-42.

10. Lopez-Arrieta BJ. Nimodipine for primary degenerative, mixed and vascular dementia, Cochrane Database of Systematic Reviews. 2002:Article no CD000147.

11. Morich F, Bieber F, Lewis JM, Kaiser L, Cutler NR, Escobar JI, et al. Nimodipine in the treatment of probably Alzheimer's disease results of two multicentre trials. Clin Drug Invest. 1996;11:185-96.

12. Facchinetti F, Fasolato C, Del Giudice E, Burgo A, Furegato S, Fusco $M$, et al. Leon, Nimodipine selectively stimulates beta-amyloid1- 42 secretion by a mechanism independent of calcium influx blockage, Neurobiol Aging. 2006;27(2):218-27.

13. Solomon, Budson AE, Memory PR. Loss: a practical guide for clinicians. Elsevier Saunders. 2011;ISBN9781416035978.

14. DMS-IV. $4^{\text {th }}$ edition, published by the American Psychiatric Association, Washington D.C.; 1994:142.

15. American Psychiatric Association. Diagnostic and Statistical Manual of Mental Disorders. $4^{\text {th }}$ ed. Washington, DC, American Psychiatric Association; 1994.

16. What is vascular dementia? Alzheimer's Society. Available at http://www.alzheimers.org.uk/site/scripts/documents _info.php?documentID=161.

17. Lee AY. Vascular dementia. Chonnam Med J. 2011;47(2):66-71.

18. Kuller LH. Hormone replacement therapy and its relationship to dementia. J Am Geriatr Soc. 1996;44:878-80.

19. Geddes, John, Gelder, Michael G.; Mayou, Richard. Psychiatry. Oxford [Oxfordshire]: Oxford University Press; 2005:141:ISBN0-19-852863-9.

20. Calleo J, Stanley M. Anxiety disorders in later life differentiated diagnosis and treatment strategies. Psychiatric Times. 2008;25(8).

21. Shin RW. Interaction of aluminum with paired helical tau is involved in neurofibrillary pathology of Alzheimer's disease. Gerontology. 1997;43 Suppl 1:1623.

22. Rösler M, Retz W, Thome J, Riederer P. Free radicals in Alzheimer's dementia: Currently available therapeutic strategies. J Neural Transm Suppl. 1998;54:2119.

23. Kastenholz B. Phytopharmaceuticals in the therapy of younger Alzheimer patients. Webmed Central Biochemistry. 2011;2(3).

24. Alzheimer's Association: 1.800.272.3900 Available at www.alz.org. Accessed on 20 July 2011.

25. Shub, Denis; Kunik, Mark E. Psychiatric comorbidity in persons with dementia: assessment and treatment strategies. Psychiatric Times. 2009;26(4).
26. Neuropathology group. Medical Research Council Cognitive Function and Aging Study. Pathological correlates of late-onset dementia in a multicentre, community-based population in England and Wales. Neuropathology Group of the Medical Research Council Cognitive Function and Ageing Study (MRC CFAS). Lancet. 2001;357(9251):169-75.

27. Wakisaka Y, Furuta A, Tanizaki Y, Kiyohara Y, Iida M, Iwaki T. Age-associated prevalence and risk factors of Lewy body pathology in a general population: the Hisayama study. Acta Neuropathol. 2003;106(4):374-82.

28. White L, Petrovitch H, Hardman J, Nelson J, Davis DG, Ross GW, et al. Cerebrovascular pathology and dementia in autopsied Honolulu-Asia Aging Study participants. Ann N Y Acad Sci. 2002;977(9):9-23.

29. Fujishiro H, Ferman TJ, Boeve BF, Smith GE, GraffRadford NR, Uitti RJ, et al. Validation of the neuropathologic criteria of the third consortium for dementia with Lewy bodies for prospectively diagnosed cases. J Neuropathol Exp Neurol. 2008;67(7):649-56.

30. Brayne REC, Dawson K, Hodges JR. The prevalence of frontotemporal dementia. Neurology. 2002;58(11):1615-21.

31. McKee A, Cantu RC, Nowinski CJ, Hedley-Whyte ET, Gavett BE, Budson AE, et al. Chronic traumatic encephalopathy in athletes: progressive tauopathy following repetitive head injury. J Neuropathol Exp Neurol. 2009;68(7):709-35.

32. Galvin JE, Pollack J, Morris JC. Clinical phenotype of Parkinson disease dementia. Neurology, 2006;67(9):1605-11.

33. Lamont P. Cognitive decline in a young adult with pre-existent developmental delay - what the adult neurologist needs to know. Practical Neurology. 2004;4(2):70-87.

34. Meade, Catherine E. Diagnosing dementia: mental status testing and beyond. Australian Prescriber. 2005;(28):11-3.

35. Langbehn, Douglas R. Predictors of diagnosis in Huntington disease. Neurology. 2007;68:1710-7.

36. Rosser, Anne, Hodges JR. Initial letter and semantic category fluency in Alzheimer's disease, Huntington's disease and progressive supranuclear palsy. Journal of Neurology, Neurosurgery and Psychiatry. 1994;57:1389-94.

37. Ho AK, Sahakian BJ, Brown RG, Barker RA, Hodges JR, Ane MN, et al. Profile of cognitive progression in early Huntington's disease. Neurology. 2003;61:1702-6.

38. Kirkwood SC, Siemers E, Hodes ME, Conneally PM, Christian JC, Foroud T. Subtle changes among presymptomatic carriers of the Huntington's disease gene. J Neurol Neurosurg Psychiatry. 2000;69:773-9.

39. Lawrence A, Hodges J, Rosser A, Kershaw A, French-Constant C, Rubinsztein D, et al. Evidence for specific cognitive deficits in preclinical Huntington's disease. Brain Pathol. 1998;121:132941. 
40. Lemiere J, Decruyenaere M, Evers-Kiebooms G, Vandenbussche E, Dom R. Cognitive changes in patients with Huntington's disease (HD) and asymptomatic carriers of the HD mutation - a longitudinal follow-up study. J Neurol. 2004;251:935-42.

41. Savla, Nayak G, Palmer BW. Neuropsychology in Alzheimer's disease and other dementia research. Current Opinions in Psychiatry. 2005(18):621-7.

42. Cummings JL. Alzheimer's disease. New Engl J Med. 2004;351:56-67.

43. Koreyzn AD, Vakhapora V. The preparation of the dememtia epidemic. J Neurol Sci. 2007;257:2-4.

44. Ferreira A, Proenca C, Serralheiro M, Araujo M. The in vitro screening for acetylcholinesterase inhibition and antioxidant activity of medicinal plants from Portugal. J Ethnopharmacol. 2006;108:31-7.

45. Fukuyama R, Mizuno $\mathrm{T}$, Mizuno $\mathrm{T}$, Mori $\mathrm{S}$. Nakajima K, Fushiki S, et al. Age-dependent change in the levels of $A \beta 40$ and $A \beta 42$ in cerebrospinal fluid from control subjects, and a decrease in the ratio of $\mathrm{A} \beta 42$ to $\mathrm{A} \beta 40$ level in cerebrospinal fluid from Alzheimer's disease patients. European Neurology. 2000;43(3):155-60.

46. Hardy JA, Higgins GA. Alzheimer's disease: the amyloid cascade hypothesis. Science. 1992;256:1845.

47. Storey E, Cappai R. The amyloid precursor protein of Alzheimer's disease and the A $\beta$ peptide. Neuropathol Appl Neurobiol. 1999;25:81-97.

48. Wilson CA, Doms RW, Lee VMY. Intracellular APP processing and $\mathrm{A} \beta$ production in Alzheimer disease. $\mathrm{J}$ Neuropathol Exp Neurol. 1999;58:787-94.

49. Rubinsztein DC. The genetics of Alzheimer's disease. Prog Neurobiol. 1997;52:447-54.

50. Goate A, Chartier-Harlin MC, Mullan M. Segregation of a missense mutation in the amyloid precursor protein gene with familial Alzheimer's disease. Nature. 1991;349:704-6.

51. Kamino K, Orr HT, Payami H. Linkage and mutational analysis of familial Alzheimer disease kindreds for the APP gene region. Am J Hum Genet. 1992;51:998-1014.

52. Clark RF, Goate AM. Molecular genetics of Alzheimer's disease. Arch Neurol. 1993;50:1164-72.

53. Milward EA, Papadopoulos R, Fuller SJ, Moir RD, Small D, Beyreuther K, et al. The amyloid protein precursor of Alzheimer's disease is a mediator of the effects of nerve growth factor on neurite outgrowth. Neuron. 1992;9:129-37.

54. Shea TB, Beermann ML, Honda T, Nixon RA. Secretion of amyloid precursor protein and laminin by cultured astrocytes is influenced by culture conditions. J Neurosci Res. 1994;37:197-207.

55. Walsh DM, Hartley DM, Kusumoto Y, Fezoui Y, Condron MM, Lomakin A, et al. Amyloid $\beta$-protein fibrillogenesis structure and biological activity of protofibrillar intermediates. J Biol Chem. 1999;274:25945-52.
56. Lazo ND, Downing DT. Amyloid fibrils may be assembled from $\alpha$-helical protofibrils. Biochemistry. 1998;37:1731-5.

57. Bandiera T, Lansen J, Post C, Varasi M. Inhibitors of A $\beta$ peptide aggregation as potential anti-Alzheimer agents. Curr Med Chem. 1997;4:159-70.

58. Maruyama K, Terakado K, Usami M, Yoshikawa K. Formation of amyloid- like fibrils in COS cells overexpressing part of the Alzheimer amyloid protein precursor. Nature. 1990;347:566-9.

59. Yamaguchi $H$, Yamazaki $T$, Ishiguro $K$. Ultrastructural localization of Alzheimer amyloid $\beta / \mathrm{A} 4$ protein precursor in the cytoplasm of neurons and senile plaque-associated astrocytes. Acta Neuropathol (Berl). 1992;85:15-22.

60. Ferreira A, Caceres A, Kosik KS. Intraneuronal compartments of the amyloid precursor protein. $\mathrm{J}$ Neurosci. 1993;13:3112-23.

61. Mann DM, Brown A, Prinja D, Davies CA, Landon M, Masters CL. An analysis of the morphology of senile plaques in Down's syndrome patients of different ages using immunocytochemical and lectin histochemical techniques. Neuropathol Appl Neurobiol. 1989;15:317-29.

62. Gandy S, Greengard P. Regulated cleavage of the Alzheimer amyloid precursor protein: molecular and cellular basis. Biochimie. 1994;76:300-3.

63. Gabuzda D, Busciglio J, Yankner BA. Inhibition of $\beta$-amyloid production by activation of protein kinase C. J Neurochem. 1993;61:2326-9.

64. Nitsch RM, Slack BE, Farber SA. Receptor-coupled amyloid precursor protein processing. Ann N Y Acad Sci. 1993;695:122-7.

65. Govoni S, Racchi M, Bergamaschi S. Defective protein kinase $\mathrm{C}_{-}$leads to impaired secretion of soluble $\beta$-amyloid precursor protein from Alzheimer's disease fibroblasts. Ann NY Acad Sci. 1996;777:3327.

66. Benussi L, Govoni S, Gasparini L. Specific role for protein kinase $\mathrm{C}$ in the constitutive and regulated secretion of amyloid precursor protein in human skin fibroblast. Neurosci Lett. 1998;240:97-101.

67. LeBlanc AC, Koutroumanis M, Goodyer CG. Protein kinase $\mathrm{C}$ activation increases release of secreted amyloid precursor protein without decreasing $A \beta$ production in human primary neuron cultures. J Neurosci. 1998;18:2907-13.

68. Nitsch RM, Deng MH, Growdon JH, Wurtman RJ. Serotonin 5-HT2a and 5-HT2e receptors stimulate amyloid precursor protein ectodomain secretion. J Biol Chem. 1996;271:4188-94.

69. Vassar R, Bennett BD, Babu-Khan S. Beta-secretase cleavage of Alzheimer's amyloid precursor protein by the transmembrane aspartic protease BACE. Science. 1999;286:735-41.

70. Selkoe DJ, Yamazaki T, Citron M. The role of APP processing and trafficking pathways in the formation of amyloid $\beta$-protein. Ann NY Acad Sci. 1996;777:57-64. 
71. Suzuki N, Cheung TT, Cai XD. An increased percentage of long amyloid $\mathrm{b}$ protein secreted by familial amyloid A $\beta$ protein precursor ( $\beta$ APP717) mutants. Science. 1994;264:1336-40.

72. Tamaoka A, Odaka A, Ishibashi Y. APP717 missense mutation affects the ratio of amyloid A $\beta$ protein species (A $\beta 1-42 / 43$ and $A \beta 1-40)$ in familial Alzheimer's disease brain. J Biol Chem. 1994;269:32721-4.

73. Citron M, Vigo-Pelfrey C, Teplow DB. Excessive production of amyloid -protein by peripheral cells of symptomatic and presymptomatic patients carrying the Swedish familial Alzheimer disease mutation Proc Natl Acad Sci USA. 1994;91:11993-7.

74. Kosaka T, Imagawa M, Seki K. The $\alpha$ APP717 Alzheimer mutation increases the percentage of plasma amyloid-Aßprotein ending at A $\beta 42(43)$. Neurology. 1997;48:741-5.

75. Cras P, van Harskamp F, Hendriks L. Presenile Alzheimer dementia characterized by amyloid angiopathy and large amyloid core type senile plaques in the APP 692Ala Gly mutation. Acta Neuropathol (Berl). 1998;96:253-60.

Cite this article as: Sekhar DS, Shwetha BK, Haimavathi B, Vikram P. The effect of calcium channel blockers against scopolamine induced cognitive impairment and oxidative stress. Int $\mathbf{J}$ Basic Clin Pharmacol 2016;5:2199-2211. 